Schulich School of Law, Dalhousie University

Schulich Law Scholars

Dipping Into a Shallow Pool or Beginning a Deeper Conversation: A Case Study of a Minister's Engagement With the Internet for Preaching

David H. Michels

Follow this and additional works at: https://digitalcommons.schulichlaw.dal.ca/scholarly_works

Part of the Library and Information Science Commons, and the Liturgy and Worship Commons 


\section{Dipping Into a Shallow Pool or Beginning a Deeper Conversation: A Case Study of a Minister's Engagement With the Internet for Preaching}

David H. Michels

To cite this article: David H. Michels (2009) Dipping Into a Shallow Pool or Beginning a Deeper Conversation: A Case Study of a Minister's Engagement With the Internet for Preaching, Journal of Religious \& Theological Information, 8:3-4, 164-178, DOI: 10.1080/10477845.2009.489814

To link to this article: https://doi.org/10.1080/10477845.2009.489814

巴nublished online: 02 Jun 2010.

Submit your article to this journal $\square$

Џلll Article views: 158

Q View related articles $\longleftarrow$

Citing articles: 18 View citing articles 4 


\title{
Dipping Into a Shallow Pool or Beginning a Deeper Conversation: A Case Study of a Minister's Engagement With the Internet for Preaching
}

\author{
DAVID H. MICHELS \\ Dalhousie University, Halifax, Nova Scotia, Canada
}

\begin{abstract}
The study considers the question "What is the pastor's experience of engagement with the Internet for preaching?" The study responds to van der Laan's work on the potential negative impact of Internet use by Protestant Christian ministers for sermon preparation. My case study ethnographically explores one minister's experience of Internet seeking (IS) for sermon preparation alongside earlier research on clergy information behavior. The respondent recounted being actively engaged with the Internet in the course of his devotional and intentional IS. He appeared to use online sources critically, and his formal IS activities for sermon preparation were comparable to earlier descriptions of clergy IS. The negative impact of the Internet, feared by van der Laan, was not apparent in this study. I found that Internet use did offer interesting possibilities for feedback and engagement during the sermon-construction process.
\end{abstract}

KEYWORDS buman information behavior, clergy, Internet, preaching

\section{INTRODUCTION}

Research Problem

In "How the Internet Shapes Religious Life, Or the Medium Is Itself the Message," J. M. van der Laan considered the use of Internet resources by

Address correspondence to David H. Michels, Sir James Dunn Law Library, Schulich School of Law, Dalhousie University, 6061 University Avenue, Halifax, NS B3H 4H9. E-mail: David.Michels@dal.ca 
American Protestant Christian ministers. Van der Laan's purpose was to understand "how pastors and parishioners rely on technology, specifically the Internet, as their guide to understand, define, and practice their religion" (272). His study was inspired by his own personal church experiences. Van der Laan explained:

Not long ago, I heard a pastor begin a sermon with a telling remark that went something like this: "As I was doing research for my message this past week, I found pertinent information on the Internet." I have to admit that for some time now my personal radar has been suspecting Internet sources of the sermon anecdotes and illustrations I have been hearing in church services. (272)

Van der Laan's methodology was to survey materials available online through sites such as eSermons.com (273). He discussed authorship, access costs, and ethical/plagiarism issues. Van der Laan then asked the question "What happens to churches and pastors and Christian religious life when those involved rely increasingly, maybe soon predominately, on such Internet sources and resources?" He concluded that this food for religious life becomes processed, diluted, and artificial: "Certainly, the sermon is sullied, and the word becomes wooden" (275). His discussion then turned to a more philosophical consideration of the impact of the Internet on religious life generally, drawing on Ellul, Dreyfus, and Kierkegaard.

On the face of this study, van der Laan made compelling arguments, raising fears about the depersonalization, commercialization, and homogenization of faith. What was missing from this study was the voice of the minister. There were no interviews or analysis of actual Internet information use in sermons. Much of van der Laan's analysis was of the marketing materials of commercial web sites. He appeared to assume that ministers might use this Internet material uncritically and that the Internet exists as an archive or pond that one can dip into for information. I would contend that the minister's relationship with the Internet is more complex than presented by van der Laan, and worth further exploration.

I sought to explore the use of the Internet in sermon preparation in a context similar to the one described by van der Laan. I focused on one case, drawn from project data of an ethnographic study of religious information seeking (IS) by church leaders. I attempted to answer the question "What is the pastor's experience of his engagement with the Internet for preaching?" Below I surveyed the literature relevant to this study and outlined my research methodology. Following this, I offered a description of the minister's congregational context, the minister's description of his preparation for preaching, and a comparative analysis of case studies of clergy IS. I returned to van der Laan's concerns in my conclusion. 


\section{LITERATURE REVIEW}

I considered literature on human information behavior (HIB), the intersecting literatures of sociology of religion and media/Internet studies, and literature on ethnographic methodology.

I assumed a constructivist approach to HIB that built on sense-making theory. It focuses on the individual's experience actively constructing meaning in his/her life contexts as developed by Dervin et al. (2003) and Kuhlthau (1993). I found that religious IS has been neglected in the analysis of everyday life IS. Despite the lack of a specific study, hints of religious information use can be identified in a number of significant studies. In Harris \& Dewdney's study of battered women, clergy were information sources. In Chatman's studies, respondents used information sources such as religious books, television, and radio. In a recent study of "information grounds," Fisher, Landry, and Naumer noted that several respondents indicated that church was an important context for unexpectedly encountering useful information. Kari and Hartel have theorized that information-seeking research has focused largely on problem-solving activities rather than the "higher things of life" (1131). There have been no studies in the information science literature that consider the impact of online IS on clergy information behavior.

Sociologists, however, have become increasingly interested in the role the Internet plays in the formation and practice of religion. Studies by Hoover and Clark explored, generally, media and religious identity including online activity. Linderman and Lövheim's studies and Campbell's study ("Community Online") specifically focused on religion and Internet. The frequency of online religious seeking has been established by studies such as Hoover, Clark, and Rainie, and recent research has begun to present a picture of what religious users are doing online (Larsen; Helland; Madden; Campbell, "Community Online"; Lövheim). Several studies have begun to explore the question of religious authority online (Campbell "Power" \& "Blogosphere"; Boutros). Campbell ("Religion and Internet") found that most research on religion, Internet, and identity has focused on adolescents and minority religious groups. Little research has been done on mainline religious practitioners or, specifically, on religious professionals.

There have been several IS studies that considered clergy as professionals. Tanner ("Information Professional"), studied the pastor as information professional, identifying a handful of articles since 1944 that he divided into (1) reading habits and (2) information needs and uses (21). He reported that survey studies on reading habits found that ministers read, on average, 18.5 hours a week (Lancour), were influenced by professional interests most in reading preferences (Hawkins), seldom used public libraries (Erdel), but had sizable personal libraries (Tanner, "Bring the Books"). However, Tanner also argued that the use of self-administered questionnaires and surveys was inadequate to fully understand these practices (25). Allen examined information 
behavior of Central American Baptist pastors and concluded that increased church leadership responsibilities and education were the strongest predictors of the use of printed materials and mass media. Porcella's dissertation, as summarized by Tanner ("Information Professional"), found "that more conservative ministers tended to value more highly the Bible and aids to Biblical interpretation while more liberal ministers used a broader range of information resources" (28).

In Tanner's own study ("Information Professional"), ministers used informal sources and their personal libraries for information gathering. Wicks' survey of earlier research noted that clergy frequently rely on networks of colleagues for information and ideas. Pastors were more likely to use computers for tasks related to preaching and administration. Another researcher cited by Wicks was Phillips, who explored clergy IS in the role of preacher. Phillips found that clergy were more likely to use formal information channels when in the preaching role and more informal channels in administrative roles.

Wicks' research focused on clergy work worlds and roles. He surveyed 378 clergy about their denominational affiliation, church demographics, and theological positions. These criteria were contrasted with the information sources clergy identified as useful in pastoral roles such as preaching. Wicks found that the more extreme the theological position, either liberal or conservative, the more likely the clergy person is to stay within his or her theological world when selecting sources for preaching (211). He also found that the denominational world did not strongly influence IS when in the preaching role (212). Baptist pastors were found to be more open to materials from other theological traditions. There was an inclination toward print sources for preaching and informal sources for other work roles such as caregiver and administrator (215). Wicks found that the Bible was repeatedly identified as the first source in the role of preacher (218) and that they preferred their own libraries or institutional ones. This suggests a preference for easily accessible materials (218). Wicks found that pastors used computers for word processing and Bible resources (219). These studies attempted to generalize from larger sample sizes; however, as Tanner ("Information Professional") argued, it is important not only to ask what sources they say they value but to observe how these are used in practice (28).

Roland considered a single case study of a clergy member's sense making behavior in sermon preparation. Using a series of interviews and analysis of sermons texts, Roland sought to determine how Scripture texts or topics were selected for preaching, what were the factors that affect how this clergy member interprets Scripture, and what goals the clergy member had for the Sunday sermon. The minister respondent did not indicate any specific use of Internet sources in sermon preparation. This offered an intriguing contrast with my case. 


\section{METHODOLOGY}

The present study is part of an ongoing ethnographic project on information behavior of leaders of churches in transition. For this study I used a microethnographic case study approach as described by Willis (241-244). I focused on one minister and his information behavior associated with the preparation of sermons. I chose this methodology because I was seeking to gather rich qualitative data that would describe respondents' perceptions as they relate to religious IS. LaCompte and Schesul argue that the intent of ethnography is to produce "a picture of cultures and social groups from the perspective of their members" (27). In HIB research, Chatman claimed, "Ethnographic studies make known contextual meanings, cultural norms, and social interactions that are not possible with other methods" (Retired Women, 3). Ethnographic methodologies have generated data that may be understood from a number of research paradigms such as interpretive/phenomenological/constructivist (LaCompte \& Schesul, 41). Williamson has argued for increased use of ethnography as a methodology in HIB research because of its suitability to constructivist approaches. Third, although this methodology has been demonstrated to be useful (Solomon, Kuhlthau, Chatman, and McKechnie), it has been largely neglected in information science research. Julien and Duggan found that in information needs and uses research studies, ethnographic methodologies were used in only 2.6\% of methods used during 1984-1998. Only a handful of studies have adopted this approach over the past decade.

Data collection included participant observation, digital video/audio recordings, archival sources, and interviewing. I began data collection by gathering general demographic information about the community, church, membership, and leadership. This is essential in understanding the ecology of the congregation (Eisland \& Warner, 40ff). I interviewed the minister about personal and professional religious IS, noting particularly the impact of online information. I gathered any books, videos, music, web sites and documents cited in the interview. I collected digital recordings of services and audio recordings of sermons for analysis. I captured online postings related to preaching from Facebook sites, Twitter, and the church web site. Using Hammersley and Paul's (157-174) guidelines for handling documentation, I gathered official sources of information Page: 9 such as denominational documents available to the respondent. Following Spradley's approaches to participant observation ("Participant Observation") and interviewing ("The Ethnographic Interview"), I attended as an observer/participant in a series of worship services. I recorded my recollections immediately following the services (Emerson, Fretz, \& Shaw). Some textual data was manually coded and interview transcripts were coded using Hyperresearch software.

I am a former Baptist minister, with significant experience in sermon preparation. The researcher knew the respondent prior to this study and 
had visited the congregation on several occasions. As an "insider" I had increased access to the church life. I was also aware of the danger of reading into the answers of the respondent based on my own personal experiences and assumptions. To reduce interviewer bias, I provided a copy of this manuscript to the respondent for comment.

\section{DESCRIPTION}

\section{The Congregational Context}

The congregation considered in this study is a conservative evangelical Protestant church, located in a suburban region of Atlantic Canada. It has an average attendance of approximately 45 to 50 persons each Sunday. The congregation meets in a modern facility that is wired for sound, video, and Internet. The facility has a wireless network. The church's community is demographically younger than the larger municipality and predominately English speaking, with above-average education and incomes levels. These demographics are significant because they reflect a similar theological context to the congregation referenced in van der Laan's article (272). Also, Noce and McKeown found that individuals with higher incomes were more likely to use the Internet - those in urban areas, those who had higher levels of education, and whose first language was English also were more likely to use the Internet. This community, statistically, would be expected to be more comfortable with the use of Internet sources and, presumably, more accepting of the use of such sources. I found that e-mail was a regular part of congregational communication. The church has a professionally designed web site using a content management system. It has embedded Google maps, a Google calendar and a Bible lookup tool called YouVersion (www.youversion.com). The web site offered audio files of sermons in mp3 format and streaming video of services using Livestream (www.livestream.com) software. The live streaming video allowed interactive chat during the service. The church maintained a Facebook (www.facebook.com) page with news and events, and the minister maintains his own Facebook page where many congregation members are listed as "friends." It is significant that some members of the congregation, even at the leadership level, did not have home access to the Internet.

\section{The Respondent's Experience}

The respondent has degrees in the humanities and education with a graduate ministry degree. This is his first pastorate, although it is his second professional career. He is computer literate and comfortable using online communication technologies. He described himself as being "reasonably successful 
TABLE 1 Minister's Information Paths

\begin{tabular}{|c|c|c|c|}
\hline Task & $\begin{array}{c}\text { Path } \# 1 \text { : } \\
\text { Intentional seeking }\end{array}$ & $\begin{array}{c}\text { Path } \# 2 \text { : } \\
\text { Devotional gathering }\end{array}$ & $\begin{array}{c}\text { Path \#3: } \\
\text { Dialoguing }\end{array}$ \\
\hline Selecting text & Bible & Bible & \\
\hline $\begin{array}{l}\text { Textual } \\
\text { exegesis }\end{array}$ & $\begin{array}{l}\text { reference books/online } \\
\text { sources (concordance: } \\
\text { print and online) }\end{array}$ & & \\
\hline $\begin{array}{l}\text { Thematic } \\
\text { study }\end{array}$ & $\begin{array}{l}\text { books (thematic) online } \\
\text { sources (commentary) }\end{array}$ & $\begin{array}{l}\text { books } \\
\text { (devotional/fiction) }\end{array}$ & \\
\hline $\begin{array}{l}\text { Lesson } \\
\text { application }\end{array}$ & & $\begin{array}{l}\text { gospel music/ } \\
\text { contemporary worship } \\
\text { (YouTube) blogs/ } \\
\text { Twitter }\end{array}$ & $\begin{array}{l}\text { Facebook blogs/Twitter } \\
\text { Face-to-face } \\
\text { conversations }\end{array}$ \\
\hline
\end{tabular}

in being able to pursue and acquire the information that I need." The interview with the respondent explored more broadly IS for faith building, rather than simply sermon preparation. In this study, I focused specifically on the work related IS activities. The respondent was asked to describe the sources he used, the significance of each, and the selection criteria used to select these sources. He was then asked to describe how he used these tools.

The respondent described two work-related paths for IS: "devotional," for which the IS was for personal spiritual development, and "intentional," for which there was a need for specific religious information usually related to sermon or religious instruction preparation (see Table 1). These two paths intertwined as serendipitous insights from devotional activities informed the construction of sermons. For example: the respondent enjoyed reading missionary biographies. These frequently offered illustrations in sermons. A third concurrent path used by the respondent was observed through analysis of sermons and online posts. This path was online dialogue, which informed sermon construction.

In the formal sermon preparation path, the respondent said he began with the Bible, and he indicated that it was the most important source alongside prayer. He would then turn to Bible reference/language tools, such as print or online concordances. One online search tool he used was BibleGateway.com. The respondent then turned to other books on Bible themes related to his sermon topic. One example was a book titled Simply Jesus and You by Joseph Stowell. This is a book on Christian living from a conservative evangelical perspective. The respondent reported that he locates print sources through the recommendations of others, visits to bookstores, and through Christian web sites. Some recommendations might be suggested by his denomination. He then searches online for additional commentary on his topic. He described both browsing and directed forms of online searching. In browsing he stated that "if I see a web site that mentions resources, I might just flip through it and follow some links and see where it leads." In 
more directed searching, when describing the value of online tools, he said that "I myself, for instance preparing for a sermon, looking in one book, this is someone's explanation of a difficult passage and I go online putting it in and all of a sudden there are 200 persons' opinions on the passage...."

In the devotional path, the respondent also indicated that he begins with the Bible as his first and key resource. He would then turn to books, but would include devotional materials or even Christian fiction such as the fiction thriller The Prophet by Frank Peretti. He also would listen to current gospel music or contemporary Christian worship music frequently through the YouTube video-sharing web site (www.youtube.com). The visual component seemed important to the respondent. He finally described turning to blogs and twitter posts.

In the third path, online dialogue, web 2.0 applications like Facebook and Twitter (twitter.com) were used to engage colleagues, friends, and congregation members in the respondent's crafting of the sermon. One example is a post on Facebook, on November 25, 2009: "It's about the Cross-Christmas music video" taken from YouTube. The respondent was taking a controversial position that the focus of Christmas should be on the death and resurrection of Christ. This resulted in several posts questioning and supporting this position, as well as discussion offline. This idea would become a key theme for the Christmas Eve service one month later. Other examples would be the posting of intended sermon topics on Facebook, such as, "The difference between doubt and denial, join me on Sunday at 11:00 am at www.[-]. - ca for an online discussion, you can even send your comments!"

There was an additional resource referenced in the interview: "And of course the resource of prayer and reflecting on things I have been reading or listening to." The respondent placed prayer as equivalent to the Bible in importance. The exact function of prayer was less clear later in the interview, where it is also described as an evaluative/discerning tool linked to reflection, after information gathering is completed.

\section{The Evaluation Process}

The respondent was asked to describe his criteria for determining how useful a resource might be for faith building and ministry. He identified the most important criterion as orthodoxy. He defined it as "theological perimeters," "because there is no point in a resource if I don't consider the information it is going to give to be valid to what I believe." The one exception was intentional seeking out of different perspectives. The concern for orthodoxy was also evident in the selection of books used both for sermon preparation and devotional reading. They all represented a conservative evangelical perspective. The respondent described orthodoxy as comparable to the criterion of 
credibility that he would use in selecting appropriate nonreligious information sources. Other criteria were usability, time, and practicality: "something I can take and use in the moment." It is significant to note that time restrictions can direct the use of certain resources. The respondent spoke about "reading through [church father] Eusebius ... I'll look at this sometime when I've got time and now I'll see if anyone pulled out of it pithy little quotes."

\section{Critical Engagement with the Internet}

The respondent's engagement with the Internet was not without critical reflection. He was asked "how would you say that technology has helped build your personal faith?" and, then, "how has technology changed the information gathering process?" He indicated that accessibility of information was a significant change for personal seeking, sermon preparation, and church decision making. He indicated that this might become an orthodoxy issue because materials from variant viewpoints are now accessible that "ten years ago you wouldn't have stumbled upon that-it wouldn't have been in your local bookstore." He suggested that his role as the "centre of Biblical truth" for the congregation has changed, and theological positions are more frequently challenged based on information found online. He also suggested that his role as teacher was changing as members sought their own information online and then would come to him to share it. The respondent voiced a concern that the capacity of the Internet to provide extensive information extends the IS process and thereby limits the role of prayer and reflection: "Sometimes I'll say, 'You know we can find an answer, I'll just look it up,' as opposed to our greatest resource-study and prayer."

\section{COMPARATIVE ANALYSIS}

\section{Previous Clergy IS Research}

In this section, I considered previous research on clergy IS alongside my respondent's IS experience. Earlier studies suggested that IS is rooted in the theological worldview of the clergy. The respondents in these earlier studies came from a Christian and predominantly Protestant orientation, as did my respondent. The respondent in my study also emphasized formal sources in sermon preparation, such as the Bible and reference tools. But he also accessed a variety of informal sources that he indicated played a role in sermon writing. This may suggest he relied on an online network of colleagues.

My respondent, like clergy in earlier studies, considered doctrinal orthodoxy to be a significant selection criterion and restricted his IS to like-minded sources. My respondent, although open to materials outside his Baptist 
denomination, did restrict himself to conservative evangelical materials, as in earlier studies. The use of print sources still dominated my respondent's source preferences, but the inclusion of audio-visual sources suggests an interesting variation from Wick's study. The respondent relied heavily on his own library but supplemented this with online sources he could access from home. On the general level, there are no significant discrepancies between earlier studies and my study data. However, I am mindful of Tanner's ("Information Professionals") concern that we consider practice in context. Roland's study is unique in its examination of clergy information use in context. I found it notable that there are no references to the use of the Internet in this process. In the following section, I compare both descriptions, seeking to understand the role of the Internet in my respondent's sermon preparation.

The respondent in Roland's study, like my respondent, reported a high degree of confidence in his ability to locate relevant sources (129). There were significant similarities between the respondents' intentional IS process, as well as several differences. One of the most notable differences was the use of the lectionary and church calendar to select an appropriate Scripture text for the sermon. The lectionary is a calendar of readings selected for each Sunday over a 3-year period and used by a number of Protestant denominations including the respondent's Lutheran denomination. The four texts designated for the upcoming Sunday constrains the preachers' choices for text and topic. The respondent in Roland's study indicated, "I almost always preach on the readings" (64), which is consistent with other research on lectionary use by various denominations (100). Baptists, with whom my respondent is most closely affiliated, were found to rarely use a lectionary. Roland suggested that further research is needed to determine how other denominational ministers choose relevant Scripture texts for preaching (138).

Roland concluded that the primary information source used by his respondent for sermon preparation was the Bible (105), as was the case in my study. Roland's respondent considered the "Book of Concord" (Tappert), the collection of creeds and confessions of the Lutheran theological tradition, his second most important information source $(103,105)$. My respondent's tradition does not have a comparable collection of doctrine; however, the respondent in my study described the use of books on Biblical and theological themes, consistent with his denomination's theology. These would serve a similar role in interpreting and applying Scripture. Roland determined that his respondent regularly engaged in study of the Scripture texts in the original languages $(102,130)$. The tools used in language study would be comparable to my respondent's use of Biblical reference tools. Although Roland's respondent indicated that Bible study books were available from his denomination, it was not clear that he used them (83). Both respondents appeared to select sources constrained by their own theological and denominational worlds. It appears that although my respondent accessed online 
versions of several of his research tools, the information sources selected by both respondents were similar, used in similar manners, and with similar priority. The intentional IS paths for both respondents were comparable.

Turning to the devotional information sources, Roland found that the respondent used few informal/devotional sources for sermon preparation. There were references to church history and a current news story that impacted the respondent's thinking (105). The role of music in Christian life was discussed several times in Roland's study (118, 119, 122, \& 131), but there was no indication that the respondent used music in relation to sermon preparation. There was no reference to devotional or fictional reading. This was a significant difference from my respondent's preparation.

The final path identified in my study was discourse. Roland's respondent met for "text studies," for a period of time, with two community ministers (86). There is a further reference to an "imagined" dialogue with his audience that prompted a midsermon adjustment of the text, in response to how he anticipated that some members of the congregation might react to his comments (199). There was no direct means of soliciting feedback identified in Roland's study, online or otherwise.

Perhaps one of the most interesting similarities between the two accounts was the role of prayer and the Holy Spirit in the sermon preparation process. Roland's respondent stated, "Sermons begin, I guess, with prayer and with a discipline" (69). He speaks of a need to "mull over" the text (126) and "to prayerfully consider, 'Okay, what is this about?" (126). The respondent repeatedly emphasized the Holy Spirit's leading in the selection of the appropriate text (136), the direction of the message (66), and affecting the listeners (104). Roland came to an interesting conclusion that "the Holy Spirit is something other than an information resource because the clergy member cannot just pull the Holy Spirit off a bookshelf, turn to the proper page, and get the answer. The Holy Spirit is the active presence of God, mysteriously and timelessly at work in the world and in the informant's life" (137). This echoes my respondent's comments about the need for prayer and reflection in his sermon-construction process. It also highlights the same ambiguity I found in situating the activity of prayer and the work of the Holy Spirit in this process.

\section{Congregational Excursus}

Although this study focused on the minister, it was helpful to consider briefly the congregation's experience. Van der Laan raised the concern of Internet plagiarism as a shortcut for sermon preparation. However, the use of the Internet is not invisible to my respondent's congregation. Three examples illustrate this.

The first example is a verbatim recitation of a well-known sermon portion from Bishop S. M. Lockridge entitled "That's my King." This text was 
downloaded from the Internet and was used as an introduction to the service. My respondent would later preach his own sermon on this theme relating it to the key ideas in Lockridge's. The respondent's original plan was to download and play a video of this sermon in the service. He opted instead to read the text. It was clear to the congregation that this was not the pastor's creation.

In the next example, the respondent used as an illustration a discussion held in an Internet forum around conspiracies and the search for a cure for cancer. He stated: "Recently, I read in one of these forums. ..." I saw no indication that the congregation found this any less appropriate than an illustration from a newspaper or television program.

The third example indicated that the respondent might himself critically challenge online behavior. During one sermon, the respondent described at length the use of web 2.0 technologies such as Facebook (www.facebook.com) and blogs to create an online presence. The sermon was on the nature of the online presence members of the congregation create and what it reveals about their own commitment to their faith. The respondent drew on an old adage among evangelical preachers that "if being Christian became a crime, would there be enough evidence to convict us?" The adage is now applied to the new online environment.

The possibility that some clergy may use Internet material surreptitiously is not discounted. However, these examples suggest that where there is no apparent stigma attached to these resources, there is no need for concealment.

\section{CONCLUSION}

I began with the question "what is the pastor's experience of this engagement with the Internet for preparation for preaching?" I sought to explore whether the concerns expressed by van der Laan were being borne out in the experience of my respondent. I conclude that the respondent did not describe an experience with the Internet that has significantly transformed intentional activities surrounding preparation for worship. The respondent viewed his engagement with the Internet as critical and careful. Further research is needed to determine whether the greater use of devotional materials is a consequence of greater online access, or the personal preferences of the respondents. It is relevant that devotional materials reportedly used by my respondent were both in print formats as well as digital formats.

Perhaps the most interesting impact of the Internet on sermon preparation was the possibility for ongoing online dialogue. As these technologies are adopted, it may become commonplace for congregation members to engage in the sermon development and even the preaching processes. It is significant that the respondent found the accessibility of information online 
both a help and a hindrance. It created the impression that there is an answer "out there," rather than that one must seek an answer through prayer and reflection, an important theme in Roland's study. The place of prayer as a source and evaluation process needs further exploration if we are to truly craft a picture of the work of the minister on- or offline.

This was an exploratory study and more work needs to done to broaden our understanding of how the minister perceives his or her work in the information age. Yet the relationship between my respondent and the Internet is more dynamic and complex than van der Laan's description. I did not find that van der Laan's fears about Internet sources materialized in my respondent's experience. What I believe I observed was not a preacher dipping into a shallow pool of information, but the beginning of a deeper conversation.

\section{WORKS CITED}

Allen, Jean Short. "Information-Seeking Patterns and Resource Use by Baptist Leaders in Three Central American Countries.” Diss. Univ of N.C. at Chapel Hill, 1987. Print.

Boutros, Alexandra. "Media and the Transformation of Religion." American Academy of Religion, Religion Media and Culture Group. Montreal, QC. 9 Nov. 2009. Panel.

Campbell, Heidi. Exploring Religious Community Online. New York: Peter Lang, 2005. Print.

- "Religion and the Internet." Communication Research Trends 26.1 (2006), 3-24. Print.

- "Religious Authority and the Blogosphere." Journal of Computer-Mediated Communication 15.2 (2010): 251-276. Web. 23 Feb. 2010.

- "Who's Got the Power? Religious Authority and the Internet." Journal of Computer-Mediated Communication 12.3 (2007): article 14. Web. 23 Feb. 2010.

Chatman, Elfreda. "The Impoverished Life-World of Outsiders." Journal of the American Society for Information Science and Technology 47.3 (1996): 193-206. Print.

—. The Information World of Retired Women. Westport, CT: Greenwood, 1992. Print.

Clark, Lynn. "U.S. Adolescent Religious Identity, the Media, and the Funky Side of Religion." Journal of Communication 52.4 (2002): 794-811. Print.

Dervin, Brenda, Lois Foreman-Wernet, \& E. Launterbach, eds. Sense-Making Methodology Reader: Selected Writings of Brenda Dervin. Cresskill, NJ: Hampton Press, 2003. Print.

Eisland, Nancy \& R. Stephen Warner. "Ecology: Seeing the Congregation in Context." Studying Congregations: A New Handbook. Eds. Nancy Ammerman et al. Nashville, TN: Abingdon Press, 1998. 40-77. Print.

Emerson, Robert, Rachel Fretz, \& Linda Shaw. Writing Ethnographic Fieldnotes. Chicago: University of Chicago Press, 1995. Print.

Erdel, Timothy. "Bring Also the Books: Studies of Ministers as Readers." Reformed Review Spring 35 (1982): 136-151. Print. 
Fisher, Karen E., C. F. Landry, \& C. Naumer. "Social Spaces, Casual Interactions, Meaningful Exchanges: 'Information Ground' Characteristics Based on the College Student Experience." Information Research 12.2 (2006): paper 291. Web. 3 Dec. 2009.

Hammersley, Martyn, \& Paul Anderson. "Documents." Ethnography: Principles in Practice. 2nd ed. New York: Routledge, 1995. 157-174. Print.

Harris, Roma, \& Patricia Dewdney. "Theory and Research on Information-Seeking." Barriers to Information: How Formal Help Systems Fail Battered Women. Westport, CT: Greenwood Press, 1994. 7-34. Print.

Hawkins, Miriam. "An Investigation of the Reading Habits of Students and Graduates of the School of Medicine and the Candler School of Theology at Emory University." Master's Thesis, Emory University, 1954. Print.

Helland, Christopher. "Surfing for Salvation." Religion 32. 4 (2002): 293-302. Print.

Hoover, Stewart. "Identity, Media and Religion." Mediating Religion: Conversations in Media, Religion and Culture. Eds. Jolyon Mitchell and Sophia Marriage. London and New York: T\&T Clark/Continuum, 2003. Print.

Hoover, Stewart, Lynn Clark, \& L. Rainie. Faith Online: 64\% of Wired Americans Have Used the Internet for Spiritual or Religious Purposes. Pew Internet \& American Life Project, 2004. Web. May 2008.

Julien, Heidi, \& Lou Duggan. "A Longitudinal Analysis of the Information Needs and Uses Literature.” Library \& Information Science Research 22.3 (2000): 291-309. Print.

Kari, Jarkko, \& Jenna Hartel. "Information and Higher Things in Life: Addressing the Pleasurable and the Profound in Information Science." Journal of the American Society for Information Science and Technology 58.8 (2007): 1131-1147. Print.

Kuhlthau, Carol C. Seeking Meaning: A Process Approach to Library and Information Services. Norwood, NJ: Ablex Publishing, 1993. Print.

LaCompte, Margaret, \& Jean Schensul, eds. Designing and Conducting Ethnographic Research. London: Alta Mira, 1999. Print. Ethnographic Toolkit Ser.

Lancour, Harold. "The Reading Interests and Habits of the Graduates of the Union Theological Seminary." Library Trends 27 (1978): 28-35. Print.

Larsen, Elana. CyberFaith: How Americans Pursue Religion Online. Pew Internet \& American Life Project. 23 Dec. 2001. Web. 15 May 2008.

Linderman, A., \& Mia Lövheim. "Internet and Religion. The Making of Meaning, Identity and Community Through Computer Mediated Communication." Mediating Religion: Conversations in Media, Religion and Culture. Eds. Jolyon Mitchell \& Sophia Marriage. London and New York: T\&T Clark/Continuum, 2003. Print.

Linderman, Alf, \& Mia Lövheim. "Constructing Religious Identity on the Internet." Religion and Cyberspace. Eds. M. Hojsgaard \& M. Warburg. London: Routledge, 2005. 121-137. Print.

Lövheim, Mia. "Virtually Boundless? Youth Negotiating Tradition in Cyberspace" Everyday Religion. Ed. Nancy T. Ammerman. Oxford: Oxford University Press, 2007. Print.

Madden, Mary. America's Online Pursuits: The Changing Picture of Who's Online and What They Do. Pew Internet \& American Life Project. 2003. Web. May 2008

McKechnie, Lynn. "Ethnographic Observation of Preschool Children." Library \& Information Science Research 22.1 (2000): 61-76. Print. 
Noce, Anthony, \& Larry McKeown. "A New Benchmark for Internet Use: A Logistic Modeling of Factors Influencing Internet Use in Canada, 2005." Government Information Quarterly 25 (2008): 462-476. Print.

Porcella, Brewster. "The Information Gathering of Protestant Ministers of Cedar Rapids, Iowa." Diss. Univ. Ill., 1973. Print.

Peretti, Frank. The Prophet. Wheaton, IL: Crossway Books, 1992. Print.

Roland, Daniel R. "Interpreting Scripture in Contemporary Times: A Study of a Clergy Member's Sense Making Behavior in Preparing the Sunday Sermon." Diss. Emporia State Univ. 2007. Print.

Solomon, Paul. "Discovering Information Behaviors in Sense Making: Time and Timing." Journal of the American Society for Information Science 48.12 (1997): 1097-1108.

Spradley, James P. The Ethnographic Interview. Toronto: Holt, Rinehart and Winston, 1979. Print.

- Participant Observation. Toronto: Holt, Rinehart and Winston, 1980. Print.

Stowell, Joseph. Simply Jesus and You. Portland, OR: Multnomah Press, 2006. Print.

Tanner, Thomas M. "Bring the Books': Results of a National Survey on Ministerial Reading Habits." Journal of Religious \& Theological Information 1.2 (1994): 53-76. Print.

- "The Pastor as Information Professional: An Exploratory Study of How the Ministers of One Midwestern Community Gather and Disseminate Information." Diss. Univ. Ill. at Urbana-Champaign, 1992. Print.

Tappert, Theodore G., ed. The Book of Concord: Confessions of the Evangelical Lutheran Church. Philadelphia: Fortress Press, 1959. Print.

Van Der Laan, J. M. "How the Internet Shapes Religious Life, or the Medium Is Itself the Message." Bulletin of Science, Technology and Society 29 (2009): 272-277. Print.

Williamson, Kirsty. (2006) "Research in Constructivist Frameworks Using Ethnographic Techniques." Library Trends 55.1 (2006): 83-101. Print.

Willis, Jerry W. Foundations for Qualitative Research: Interpretive and Critical Approaches. Thousand Oaks: Sage, 2007. Print. 